\title{
Paranasal Sinus Non-Hodgkin Lymphoma
}

National Cancer Institute

\section{Source}

National Cancer Institute. Paranasal Sinus Non-Hodgkin Lymphoma. NCI Thesaurus.

Code C6069.

A non-Hodgkin lymphoma that arises from the paranasal sinus. Representative examples include diffuse large B-cell lymphoma and extranodal NK/T -cell lymphoma, nasal type. 